\title{
Application of ultraviolet light as an indoor disinfectant
}

\author{
Hafizhul Khair ${ }^{1 *}$, Isra Suryati ${ }^{1}$, Rahmi Utami ${ }^{1}$ \\ ${ }^{1}$ Teknik Lingkungan, Fakultas Teknik, Universitas Sumatera Utara \\ *Email: hafizhul@usu.ac.id
}

\begin{abstract}
WHO announced a new outbreak disease, COVID-19, as a public health emergency that has plagued the world since January 30, 2020. Critical readiness and response are needed, such as equipping healthcare workers and facility management with important information, procedures, and tools to be safe and working effectively in responding to the outbreak. One of the critical hospital's services facilities is an isolation room/inpatient room. This room needs to be sterilized using a disinfectant regularly. The use of disinfectants, such as chemical fluids can only kill vegetative cells from microbes/viruses. Microbes/viruses, especially in the form of vegetative cells, could be killed by ultraviolet exposure. The objectives of this service program are: (1) Improving the cleanliness of hospital inpatient rooms so that they can be used immediately in treating patients (2) Speeding up the process of cleaning/sterilizing hospital inpatient rooms/isolation given the increasing number of patients in monitoring for covid-19 cases. The problem with inpatient sanitation/isolation in hospitals is usually many microbes in the indoor air. Clean and sterile inpatient/isolation rooms are needed in the patient's care. Therefore, it is necessary to improve the process of cleaning /sterilizing the inpatient room/isolation in the hospital by using UV exposure.
\end{abstract}

\section{Keyword: ultraviolet lamps, isolation rooms, hospitals, sterilization, viruses}

\begin{abstract}
Abstrak
WHO mengumumkan wabah penyakit baru yaitu COVID-19 sebagai Kedaruratan Kesehatan Masyarakat yang meresahkan dunia sejak 30 Januari 2020. Untuk menanggapi COVID-19, diperlukan kesiapan dan tanggapan yang bersifat kritis seperti memperlengkapi tenaga kesehatan dan manajemen fasilitas pelayanan kesehatan dengan informasi, prosedur, dan alat yang penting agar dapat aman dan efektif bekerja. Salah satu fasilitas pelayanan rumah sakit adalah ruang isolasi/ruang rawat inap. Ruangan ini perlu disterilisasi dengan menggunakan desinfektan. Penggunaan desinfektan seperti cairan kimia hanya dapat membunuh sel vegetatif dari mikroba/virus. Mikroba/virus terutama dalam bentuk sel vegetatifnya akan terbunuh dengan penyinaran sinar UV. Tujuan dari program kegiatan pengabdian ini, yaitu: (1) Meningkatkan kebersihan ruang rawat inap/isolasi rumah sakit sehingga dapat segera digunakan dalam merawat pasien (2) Mempercepat proses pembersihan/sterilisasi ruang rawat inap/isolasi rumah sakit mengingat semakin meningkatnya jumlah pasien dalam pemantauan untuk kasus COVID-19 ini. Permasalahan terkait sanitasi ruang rawat inap/isolasi di rumah sakit biasanya adalah banyaknya mikroba di udara dalam ruangan. Ruang rawat inap/isolasi yang bersih dan steril sangat dibutuhkan dalam merwat pasien. Oleh sebab itu, dibutuhkan peningkatan proses pembersihan/sterilisasi ruang rawat inap/isolasi di rumah sakit dengan menggunakan penyinaran sinar UV.
\end{abstract}

Kata Kunci: lampu ultraviolet, ruang isolasi, rumah sakit, sterilisasi, virus

\section{PENDAHULUAN}

Pada 31 Desember 2019, WHO China Country Office melaporkan kasus pneumonia yang tidak diketahui etiologinya di Kota Wuhan, Provinsi Hubei, Cina. Pada tanggal 7 Januari 2020, Cina mengidentifikasi pneumonia yang tidak diketahui etiologinya tersebut sebagai jenis baru coronavirus (coronavirus disease, COVID-19). Pada tanggal 30 Januari 2020 WHO telah menetapkan sebagai Public Health Emergency of International Concern (PHEIC). Penambahan jumlah kasus COVID-19 berlangsung cukup cepat dan sudah terjadi penyebaran ke luar wilayah Wuhan dan negara lain termasuk Indonesia (Kementerian Kesehatan, 2020).

Sampai dengan tanggal 5 April 2020, dilaporkan total kasus konfirmasi 1.273.713 dengan 64.459 kematian (CFR 7\%) dimana kasus dilaporkan di 208 negara/wilayah (Worldometer, 2020). 
Diantara kasus tersebut, sudah ada beberapa petugas kesehatan yang dilaporkan terinfeksi. Pada tanggal 2 Maret 2020, Indonesia melaporkan kasus konfirmasi COVID-19 sebanyak 2 kasus. Sampai dengan tanggal 6 April 2020, Indonesia sudah melaporkan 2.273 kasus konfirmasi COVID-19 dengan angka kematian yang paling tinggi di Asia Tenggara yaitu $\pm 8 \%$.

Salah satu cara mencegah virus Corona yang direkomendasikan WHO adalah dengan penyemprotan cairan disinfektan. WHO dalam situs resminya memberikan formula membuat disinfektan mandiri dengan bahan yang tersedia di rumah tangga, yakni alkohol dan sodium hipoklorit atau cairan pemutih. Takaran yang direkomendasikan adalah pengenceran 5 persen sodium hipoklorit dalam air dengan perbandingan 1:1000. Namun WHO tidak merekomendasikan mencampurnya dengan chloride. Cairan disinfektan bisa membunuh bakteri dan virus dalam rentang 10-60 menit setelah penyemprotan dilakukan (World Health Organization, 2020). Hal ini karena efek kandungan klorin dalam cairan pemutih. Maka perlu dilakukan penyemprotan secara rutin di ruang-ruang rumah sakit yang intens menerima pasien baik yang ODP (Orang Dalam Pemantauan), PDP (Pasien Dalam Pemantauan) maupun postif COVID-19.

Namun dalam praktiknya masyarakat tak hanya menyemprot disinfektan ke ruangan atau benda, tapi juga tubuh. Sehingga setiap orang atau kendaraan yang melewatinya secara otomatis terkena semprotan disinfektan. Begitupun praktik pada bilik disinfektan yang tersebar di banyak tempat lainnya. WHO kembali menegaskan bahwa menyemprotkan cairan disinfektan ke sekujur tubuh tak akan membunuh virus Corona atau bernama resmi COVID-19. Karena virus tersebut telah masuk ke dalam tubuh, sementara cairan disinfektan hanya sampai di luar tubuh.

Klorin (Cl2) merupakan salah satu unsur yang ada di bumi dan jarang dijumpai dalam bentuk bebas. Dalam kehidupan manusia, klorin digunakan sebagai desinfektan dalam pengolahan air minum, pemutih dan penghalus pada industri tekstil, pulp dan kertas, pestisida, industri kimia seperti penghasil PVC, PLTU sebagai pengontrol biological fouling, dll. Maraknya penggunaan cairan desinfektan sejak wabah COVID-19 ini tentunya berdampak negatif baik terhadap lingkungan maupun kesehatan manusia. Dampak negatif penggunaan klorin terhadap lingkungan adalah penipisan lapisan ozon dan pemanasan global. Penggunaan klorin yang berlebihan bisa berdampak pada kesehatan manusia. Sifat Klorin yang sangat reaktif akan sangat mudah bereaksi membentuk senyawa organoklorin yang bersifat toksik dan karsinogenik bagi manusia (Hasan, 2006).

Meningkatnya jumlah pasien dalam pengawasan dari wabah COVID-19 ini tentunya membutuhkan ruang rawat atau ruang isolasi yang banyak di rumah sakit. Ruang isolasi perlu dijaga dalam kondisi steril. Rumah Sakit Universitas Sumatera Utara (RS USU) direncanakan akan menjadi rumah sakit penyangga selama wabah COVID-19 ini mengingat keterbatasan rumah sakit rujukan pemerintah untuk penanganan COVID-19 di Kota Medan. Jumlah ruang rawat inap di RS USU terbagi atas kelas I, II dan III dengan jumlah total ruangan adalah 26 ruangan atau 434 tempat tidur (USU, 2020).

Peraturan Menteri Kesehatan No. 7 tahun 2019 tentang Kesehatan Lingkungan Rumah Sakit, Pasal 3, Ayat 3 yang berbunyi penyehatan dilakukan terhadap media lingkungan berupa air, udara, tanah, pangan serta sarana dan bangunan. Amanah dari peraturan ini adalah bahwa menjaga kesehatan lingkungan sangat penting dalam melindungi sumber daya manusia rumah sakit, pasien, pengunjung dan masyarakat di sekitar rumah sakit (Peraturan Menteri Kesehatan Republik Indonesia Nomor 7 Tahun 2019 Tentang Kesehatan Lingkungan Rumah Sakit, 2019). Pengendalian lingkungan di fasilitas pelayanan kesehatan, antara lain berupa upaya perbaikan kualitas udara, kualitas air, dan permukaan lingkungan, serta desain dan konstruksi bangunan, dilakukan untuk mencegah transmisi mikroorganisme kepada pasien, petugas dan pengunjung (Peraturan Menteri Kesehatan Republik Indonesia Nomor 27 Tahun 2017 Tentang Pedoman Pencegahan Dan Pengendalian Infeksi Di Fasilitas Pelayanan Kesehatan, 2017).

Angka kuman udara yang melebihi baku mutu akan berdampak negatif dan berisiko terhadap orang yang beraktivitas pada ruangan tersebut karena dapat menyerang system kekebalan tubuh paling luar yaitu pada saat orang tersebut dalam kondisi yang lemah. Selain itu, angka kuman udara yang tinggi mengindikasikan adanya spora jamur dalam jumlah yang banyak, dan sangat berisiko jika udara terhirup (Denning et al., 2013). 
Ada berbagai cara untuk menurunkan angka kuman di udara, secara teknis yaitu dengan penyempurnaan prosedur pembersihan, pembersihan sistem ventilasi, penyempurnaan bangunan, sedangkan secara non teknis dilakukan seperti peningkatan pengawasan dan mengadakan pendidikan serta pelatihan bagi petugas kebersihan ruangan (Bahri, 2010). Oleh karena dampak negatif klorin baik terhadap manusia dan lingkungan maka diperlukan alternative untuk menggantikan klorin sebagai desinfektan ruangan. Salah satu alternative yang bisa dilakukan adalah dengan menggunakan sinar ultraviolet sebagai pengganti desinfektan.

Berdasarkan penelitian Kristanti (Emanuel, 2012), tentang efektivitas sinar ultraviolet dalam menurunkan angka kuman udara di rumah sakit Daerah Istimewa Yogyakarta menunjukkan hasil bahwa radiasi sinar UV dapat efektif menurunkan angka kuman udara sebesar 50-100 \%, dengan suhu dan kelembaban berpengaruh terhadap adanya angka kuman di udara.

Mekanisme kerja sinar ultraviolet adalah absorpsi oleh asam nukleat tanpa menyebabkan kerusakan pada permukaan sel, energi yang diabsorpsi ini akan menyebabkan terjadinya ikatan antara molekul-molekul timin yang bersebelahan dan menyebabkan terbentuknya dimer timin sehingga fungsi dari asam nukleat terganggu dan mengakibatkan kematian bakteri (Ariyadi \& Dewi, 2009). Berdasarkan latar belakang dan analisis studi dari permasalahan di atas maka rumusan masalah dalam proposal pengabdian masyarakat ini adalah melonjaknya jumlah PDP (Pasien Dalam Pengawasan) dalam Pandemi COVID-19 memerlukan ruangan isolasi di rumah sakit yang steril untuk penanganan pasien yang lebih cepat sementara itu pemakaian desinfektan secara kimiawi yang tidak terkontrol dapat menimbulkan dampak negatif baik untuk kesehatan manusia maupun lingkungan.

\section{METODE PELAKSANAAN}

Kegiatan pengabdian masyarakat ini dilaksanakan di Rumah Sakit Universitas Sumatera Utara yang beralamat di Jl. Dr. Mansyur No.66, Merdeka, Kec. Medan Baru, Kota Medan, Sumatera Utara 20154. Untuk menyukseskan kegiatan pengabdian ini sehingga dapat mencapai luaran yang diharapkan maka dilakukan beberapa metode yaitu:

1. Studi literatur

Studi ini dilakukan untuk menentukan teknologi alternatif untuk melakukan desinfektan secara aman, cepat dan efektif. Studi literatur bersumber dari jurnal penelitian (e-journal) dan buku terkait penggunaan sinar UV sebagai desinfektan.

2. Penentuan Lokasi

Penentuan lokasi mitra disesuaikan dengan kondisi eksisting. Pada pengabdian masyarakat ini, lokasi mitra yang dituju adalah mitra yang sangat membutuhkan ruangan steril untuk merawat pasien yang terkena wabah COVID-19. Sehingga mitra yang diusulkan dalam pengabdian ini adalah Rumah Sakit USU dengan pertimbangan bahwa Rumah Sakit USU merupakan salah satu rumah sakit yang direncanakan sebagai pendukung Rumah Sakit Adam Malik dalam penanganan pasien terkena wabah COVID-19.

3. Pembuatan Alat Lampu UV (Lihat Gambar 2.1.)

Pembuatan alat, diawali dengan pembelian perangkat dan bahan serta dilanjutkan dengan perakitannya. Alat Lampu UV ini terdiri dari:
a. Lampu UV
b. Rangka Besi
c. Tombol ON/OFF
d. Kabel
e. Arduino
f. Sensor
g. Dll 


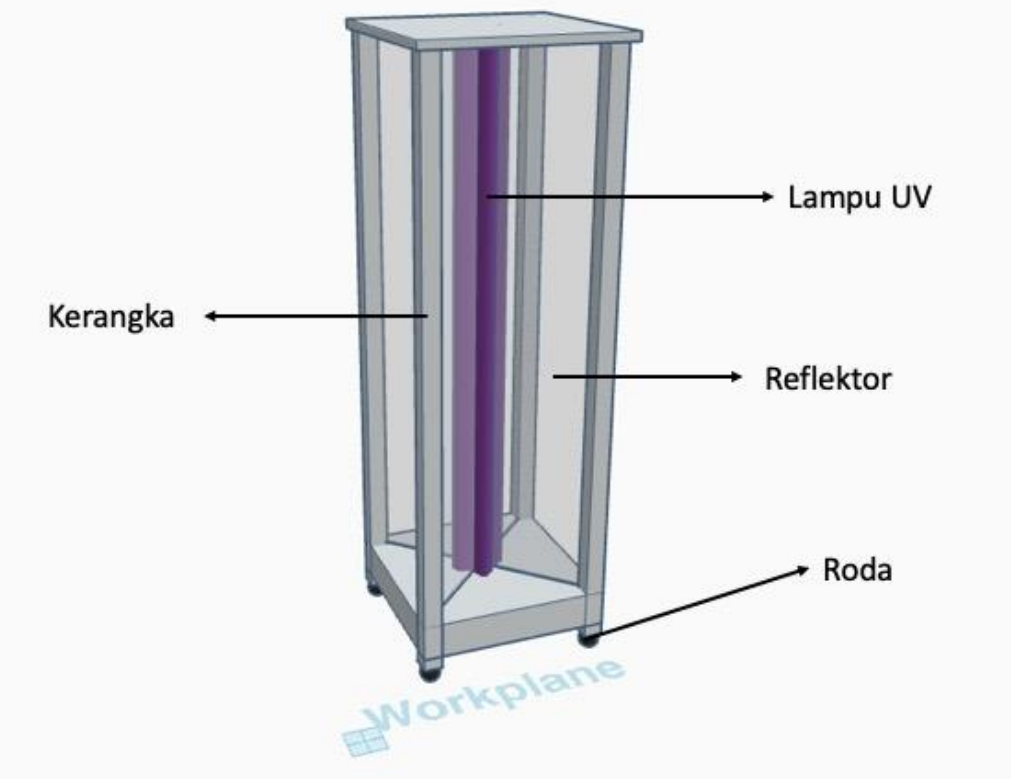

Gambar 2.1. Rancangan Rangkaian Alat Lampu UV sebagai Pengendali Virus Dalam Ruangan

4. Penyusunan Standar Operasional Prosedur (SOP) Penggunaan Alat Desinfeksi UV

Penyusunan SOP penggunaan alat ini bertujuan membantu operator dalam mengoperasikan alat, mitigasi bahaya yang ditimbulkan dan tindakan penanganan bahaya.

5. Pengujian alat

Untuk mengetahui keberhasilan penerapan alat yang dirancang maka perlu diadakan pengujian. Dari pengujian akan diperoleh informasi tentang kemampuan alat atau kinerja alat apakah dapat bekerja dengan baik sesuai dengan yang diharapkan untuk meningkatkan efisiensi dalam mengurangi mikroorganisme dalam ruangan.

6. Monitoring, Evaluasi dan Pelaporan

Monitoring dan evaluasi bertujuan untuk memantau sejauh mana alat desinfektan UV tersebut bekerja dan mengevaluasi kendala-kendala yang mungkin timbul pada saat penerapan alat tersebut. Setiap kegiatan mulai dari survei sampai penerapan dan pengujian alat dilakukan pembuatan laporan.

\section{HASIL DAN PEMBAHASAN}

Sebagai salah satu alternatif pengganti desinfektan cair ialah pembuatan alat desinfektan berbasis sinar UV. Ultraviolet (UV) merupakan suatu radiasi elektromagnetik yang mempunyai panjang gelombang lebih pendek daripada sinar violet yang berkisar dari $100-400$ nanometer. Spektrum dari sinar UV dapat dibedakan menjadi tiga, yaitu: UVA (320-400) nm, UVB (280-320) nm, dan UVC (200-280) nm (Andani, 2014).

Alat UV yang akan dibuat ini akan berkekuatan $4 \times 24$ watt yang mampu mensterilkan ruangan seluas 25-meter persegi. Berbeda dengan desinfektan cair, salah satu keunggulan menggunakan desinfeksi UV ini adalah tidak menghasilkan produk samping yang berbahaya dan tidak beracun bagi lingkungan. Metode ini adalah alternatif yang sangat diterima, aman dan hemat biaya yang tidak menghasilkan produk sampingan atau residu kimia yang dapat membahayakan lingkungan. Sederhananya, disinfeksi UV tidak menambah apa pun pada material selain sinar UV itu sendiri. 


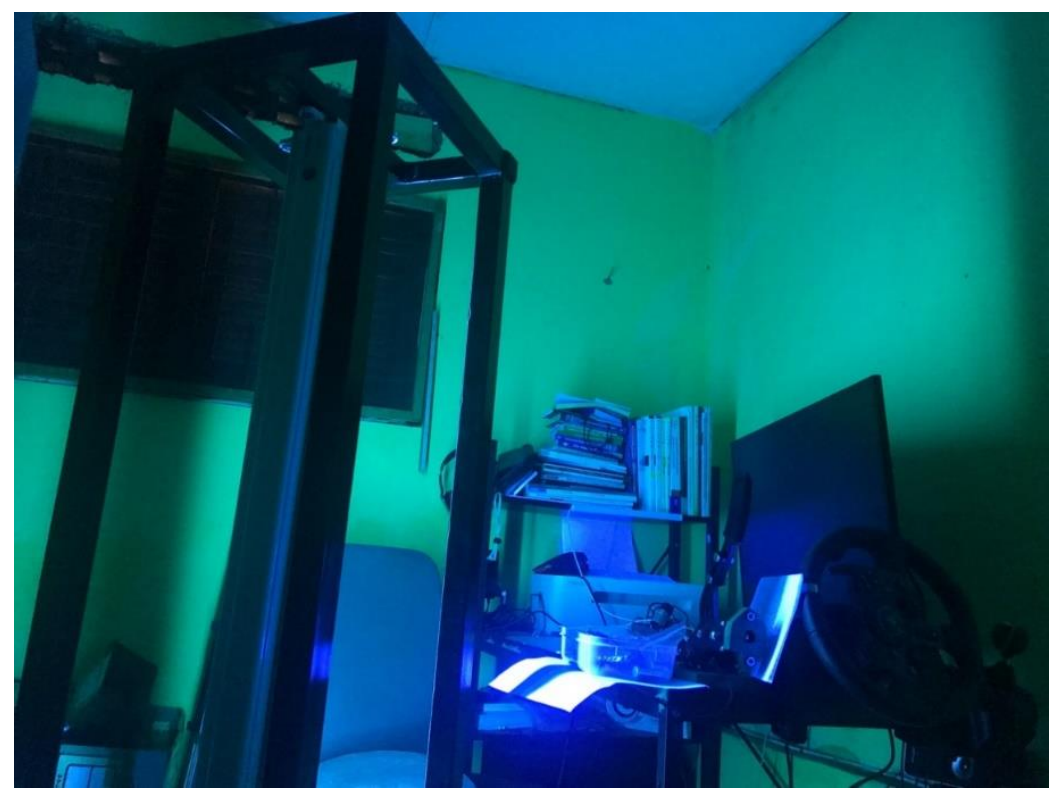

Gambar 3.1. Tahapan pengujian alat

Alat desinfeksi UV ini dapat dimanfaatkan dalam banyak aspek, alat ini dapat digunakan untuk mensterilkan udara, air atau cairan dan juga permukaan untuk berbagai material. Salah satu yang mesti diperhatikan adalah jangan menggunakan alat desinfeksi UV ini untuk manusia, hewan dan makhluk hidup lainnya, karena kemampuannya yang dapat mengubah susunan DNA.

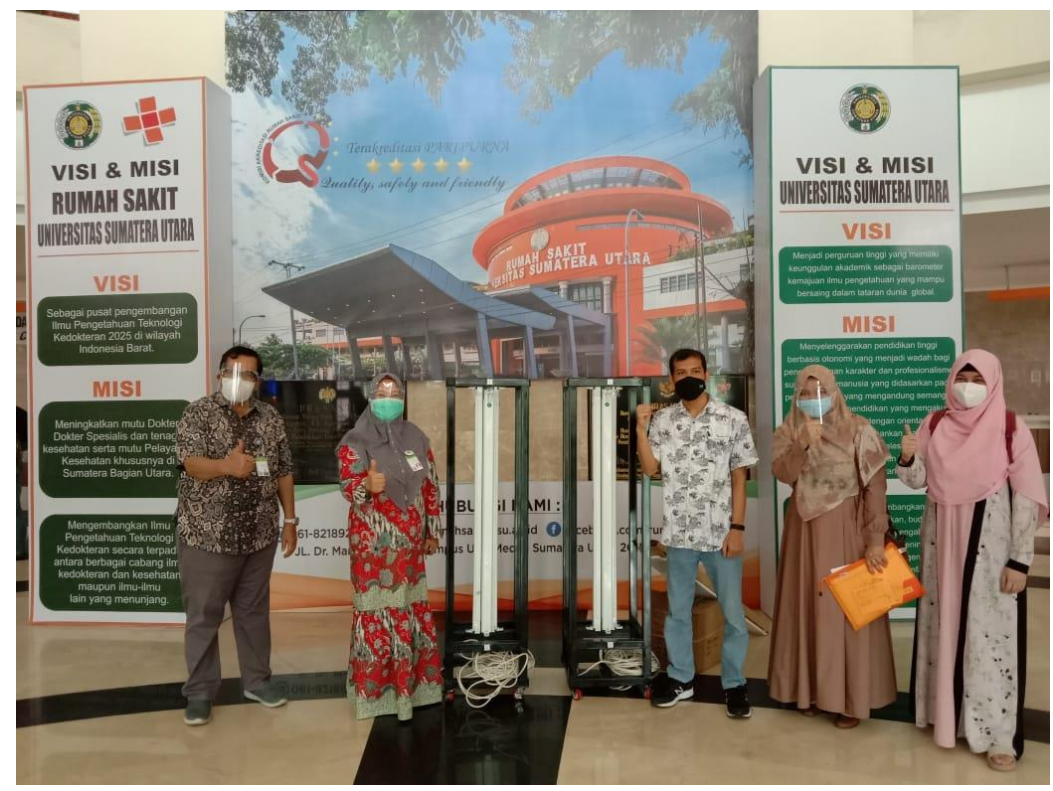

Gambar 3.2. Serah terima alat desinfektan UV di RS USU (dari kiri ke kanan: Dr.dr. Nazaruddin Sp. An (K)/Anggota Dewan Pengawas RS USU, dr. Sake Juli Martina. SpFK/Direktur Diklat, Penelitian dan Kerjasama RS.USU dengan tim pengabdian masyarakat.

\section{KESIMPULAN}

Pengabdian masyarakat di Rumah Sakit Universitas Sumatera Utara dilakukan untuk membantu mengatasi sebaran penyakit di udara seiring dengan mewabahnya penyakit baru yaitu COVID-19. Rumah sakit menjadi salah satu tempat yang paling rawan dalam penyebaran penyakit jika tidak 
diberikan perhatian yang serius. Salah satunya adalah fasilitas ruang isolasi/ruang rawat inap. Ruangan ini perlu disterilisasi dengan desinfektan secara terus menerus. Solusi untuk permasalah tersebut adalah penyediaan alat desinfeksi UV. Satu unit alat desinfektan yang dibuat dilengkapi dengan empat buah lampu. Intensiatas sinar yang dihasilkan sekitar 4x24 watt, yang cukup untuk mendesinfeksi ruangan $5 \times 5$ meter.

Sinar UV merupakan salah satu alternatif desinfektan yang dapat digunakan untuk mendesinfeksi ruangan. Penggunaan desinfektan UV memberikan kelebihan lain yaitu tanpa ada bekas pada material yang didesinfeksi dan ini tidak bisa terjadi ketika menggunakan desinfektan cair.

\section{UCAPAN TERIMAKASIH}

Penulis mengucapkan terima kasih kepada LPPM USU telah mendukung kami selama proses persiapan hingga pelaksanaan pengabdian ini.

\section{DAFTAR PUSTAKA}

Andani, R. (2014). The Effect of Ultraviolet (UV) C Lamp Exposure on Organ Weights and Histopathology Appearance Liver in Male Mice (Mus musculus L.). Jurnal Majority.

Ariyadi, T., \& Dewi, S. (2009). PENGARUH SINAR ULTRA VIOLET TERHADAP PERTUMBUHAN BAKTERI Bacillus sp. SEBAGAI BAKTERI KONTAMINAN. Jurnal Kesehatan (Bandar Lampung).

Bahri, S. (2010). Angka Kuman Udara Ruang Perawatan Bayi Di Rumah Sakit Umum Daerah (RSUD) dr. H. Soemarno Sosroatmodjo Kuala Kapuas. In POLITEKNIK KESEHATAN BANJARMASIN.

Denning, D. W., Pleuvry, A., \& Cole, D. C. (2013). Global burden of chronic pulmonary aspergillosis complicating sarcoidosis. European Respiratory Journal. https://doi.org/10.1183/09031936.00226911

Emanuel, K. (2012). Efektivitas Penggunaan Radiasi Sinar Ultraviolet Dalam Penurunan Jumlah Angka Kuman Ruang Operasi Rumah Sakit di Daerah Istimewa Yogyakarta. University of Gadjah Mada.

Hasan, A. (2006). Dampak penggunaan klorin. J. Tek. Lingk. P3TL-BPPT.

Peraturan Menteri Kesehatan Republik Indonesia Nomor 27 Tahun 2017 Tentang Pedoman Pencegahan dan Pengendalian Infeksi di Fasilitas Pelayanan Kesehatan, (2017).

Kementerian Kesehatan. (2020). FAQ Kementerian Kesehatan. https://www.kemkes.go.id/folder/view/full-content/structure-faq.html

Peraturan Menteri Kesehatan Republik Indonesia Nomor 7 Tahun 2019 Tentang Kesehatan Lingkungan Rumah Sakit, Kementerian Kesehatan RI (2019).

USU, R. S. (2020). Profil Rumah Sakit USU. Rumah Sakit USU. http://rumahsakit.usu.ac.id/index.php/id/about/message

World Health Organization. (2020). Materi Komunikasi Risiko COVID-19 untuk Fasilitas Pelayanan Kesehatan. World Health Organization.

Worldometer. (2020). Coronavirus Updates. Woldometer. https://www.worldometers.info/ 